\title{
LLNL PuPS Weld Qualification Plan
}

D. Riley, K. E. Dodson

August 24, 2001

U.S. Department of Energy

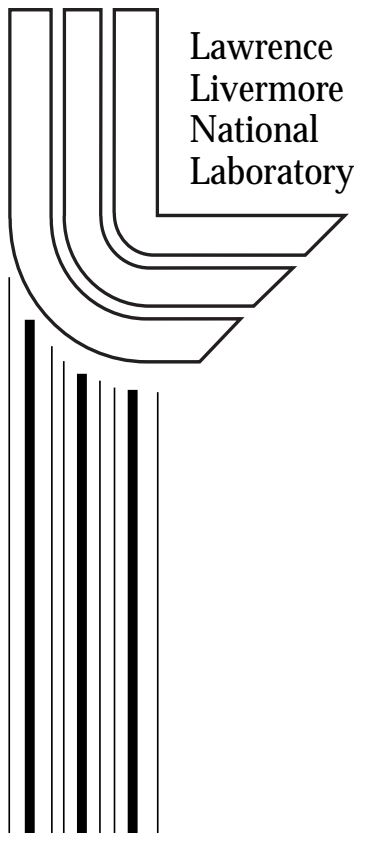




\section{DISCLAIMER}

This document was prepared as an account of work sponsored by an agency of the United States Government. Neither the United States Government nor the University of California nor any of their employees, makes any warranty, express or implied, or assumes any legal liability or responsibility for the accuracy, completeness, or usefulness of any information, apparatus, product, or process disclosed, or represents that its use would not infringe privately owned rights. Reference herein to any specific commercial product, process, or service by trade name, trademark, manufacturer, or otherwise, does not necessarily constitute or imply its endorsement, recommendation, or favoring by the United States Government or the University of California. The views and opinions of authors expressed herein do not necessarily state or reflect those of the United States Government or the University of California, and shall not be used for advertising or product endorsement purposes.

This work was performed under the auspices of the U. S. Department of Energy by the University of California, Lawrence Livermore National Laboratory under Contract No. W-7405-Eng-48.

This report has been reproduced directly from the best available copy.

Available electronically at http://www.doc.gov/bridge

Available for a processing fee to U.S. Department of Energy

And its contractors in paper from

U.S. Department of Energy

Office of Scientific and Technical Information

P.O. Box 62

Oak Ridge, TN 37831-0062

Telephone: (865) 576-8401

Facsimile: (865) 576-5728

E-mail: reports@adonis.osti.gov

Available for the sale to the public from

U.S. Department of Commerce

National Technical Information Service

5285 Port Royal Road

Springfield, VA 22161

Telephone: (800) 553-6847

Facsimile: (703) 605-6900

E-mail: orders@ntis.fedworld.gov

Online ordering: http://www.ntis.gov/ordering.htm

OR

Lawrence Livermore National Laboratory

Technical Information Department's Digital Library

http://www.llnl.gov/tid/Library.html 


\section{LLNL PUPS WELD QUALIFICATION PLAN}

Revision 2

March 28, 2001

Prepared by:

David Riley

Date

PuPS Principal Investigator

Approved by:

Karen E. Dodson

Date

PuPS LLNL Project Manager 


\section{LLNL PUPS WELD QUALIFICATION PLAN}

TABLE OF CONTENTS

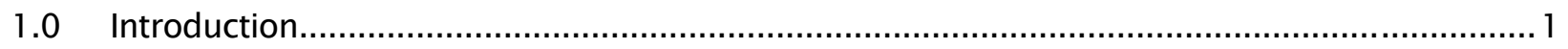

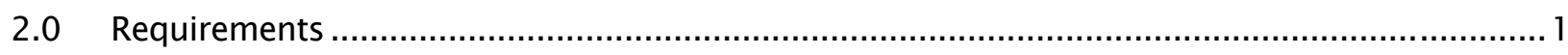

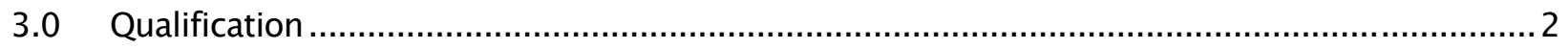

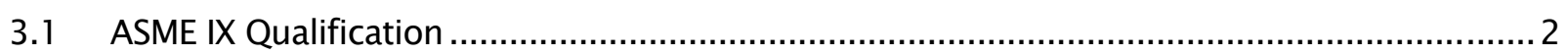

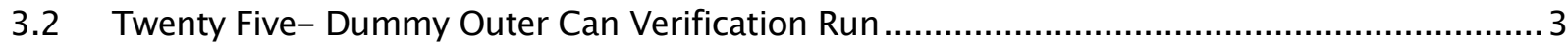

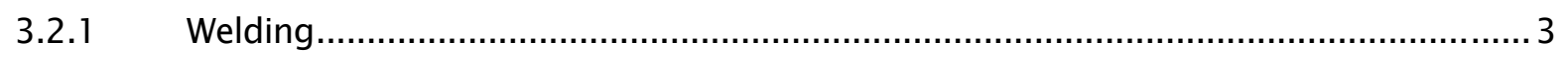

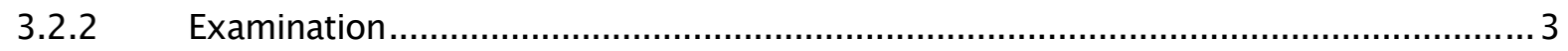

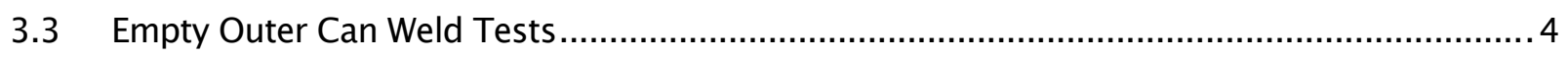

4.0 Process Control and Verification During Production ........................................................ 4

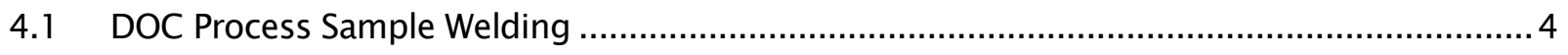

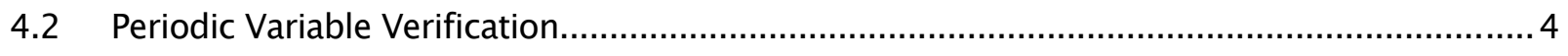

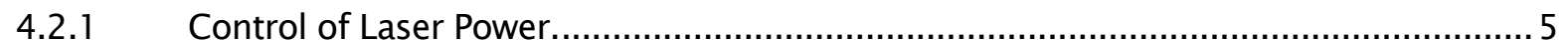

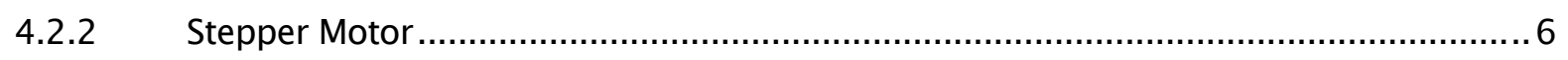

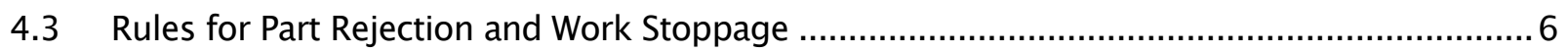

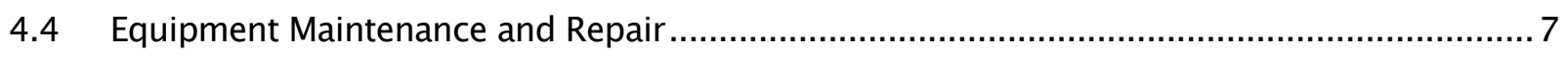

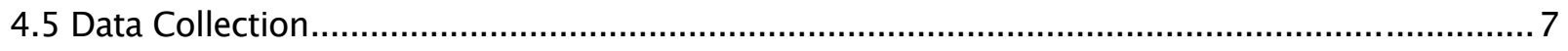

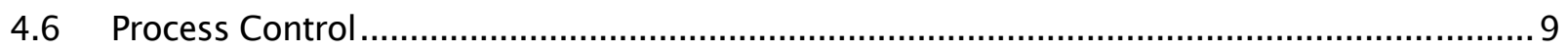

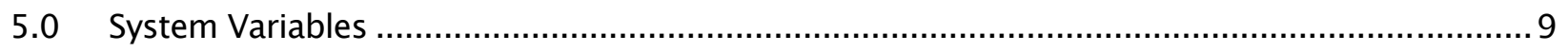

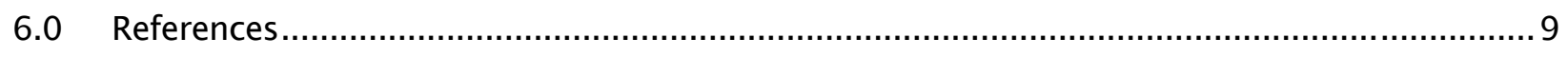

Appendix 1: PuPS ASME IX Weld Qualification Compliance Matrix ............................................. 1-1

Appendix 2:PuPS Inspection and Test Requirements ............................................................. 2-1

Appendix 3: LLNL PuPS Data Collected for Laser Weld Process Control ......................................... 3-1 


\section{LLNL PUPS WELD QUALIFICATION PLAN}

\section{1) Introduction}

This plan ensures the quality of the Lawrence Livermore National Laboratory (LLNL) DOE 3013 Standard Plutonium Packaging System (PuPS) can welds meet the requirements stipulated in the DOE Standard 3013-00 "Stabilization, Packaging, and Storage of Plutonium-Bearing Materials" (Reference 1) and G-ESR-G-00035, Revision 1 dated July 26, 2000, "Savannah River Site Stabilization and Packaging Requirements for Plutonium Bearing Materials for Storage." (Reference 2) This plan also meets the requirements for a weld qualification plan as stipulated in the G-ESR-G-00035.

The Outer Can weld must meet ASME VIII \& IX. The Outer Can welds will be evaluated initially and during production. The initial evaluation will be done by performing the following: ASME IX welding procedure qualification, ASME IX operator qualification, and a 25 can Dummy Outer Can (DOC) verification run. During production, product cans and DOCs will be evaluated. Product cans will be evaluated by a combination of visual examination of the weld faces and the use of helium leak checking. The DOCs will be examined by visual examination, leak check, radiographic examination and metallographic examination. Appendix 2 summarizes the requirements of each of these evaluations.

The Inner Can weld must meet the leak tightness requirements of DOE 3013. The Inner Can weld, while not required to meet ASME requirements, will be controlled as described in this plan to ensure a reliable leak path barrier and consistent production processing behavior. The product Inner Cans will be evaluated by a combination of visual examination of the weld faces and the use of helium leak checking.

\section{2) Requirements}

These requirements for the welds are described in the documents listed below:

DOE Standard 3013-00 "Stabilization, Packaging, and Storage of Plutonium-Bearing Materials" (Reference 1),

G-ESR-G-00035, "Savannah River Site Stabilization and Packaging Requirements for Plutonium Bearing Materials for Storage," Revision 1 dated July 26, 2000 (Reference 2),

DOE Order 440.1A Attachment 1, Section 6 (Reference 3),

ASME Boiler and Pressure Vessel Section VIII, Division 1 (Reference 4),

This section of the ASME code specifies the requirements for the pressure vessel design, fabrication, examination, and testing. Such requirements as weld penetration, weld shape, maximum size of linear and round defects are included in this section.

ASME Boiler and Pressure Vessel Section IX (Reference 5)

This section of the ASME code specifies the requirements for qualifying the welding procedure and welding operators. It also specified which variables are essential and what range of variation in each essential variable must be held without another procedure qualification.

ASME Boiler and Pressure Vessel Section V (Reference 6)

This section of the ASME code specifies the procedures that must be followed for nondestructive examination (NDE) of pressure vessels. 


\section{LLNL PUPS WELD QUALIFICATION PLAN}

In addition to the requirements specified in the above documents, LLNL has imposed additional requirement, as described in this plan, to ensure product quality.

\section{3) Qualification}

The following activities will be conducted during the weld qualification phase.

3.1 ASME IX Qualification

3.2 Twenty Five- Dummy Outer Can Verification Run

3.3 Empty Outer Can Weld Tests

\subsection{ASME IX Qualification}

LLNL Operators become qualified to perform all operations on the PuPS by receiving onthe-job training and performing qualifying welds. The Outer Can welds will be qualified to meet ASME VIII and IX. Operators will become ASME IX qualified by performing one of the following tests:

1) Performing a successful PQR weld during the ASME IX qualification. The welds will be radiographically examined, tensile and bend tested per ASME IX, and metallographically examined. Metallographic sections must not show evidence of: lack of fusion, incomplete penetration, or cracks. The metallographic samples will be checked for proper weld depth and width.

2) Performing a successful weld on a DOC. Each weld will be sectioned metallographically and the cross sections must meet the requirements of ASME IX, QW362.

The ASME qualification of the Outer Can weld will be done to all the requirements of ASME Section IX. This specification requires that each "essential variable" be measured and documented during qualification and then controlled during production within ASMEtolerances. The "essential variables" are defined for laser welding in Table QW-264 of ASME IX. Appendix 1, the "PuPS ASME IX Weld Qualification Compliance Matrix," is a table of these "essential variables," showing how the LLNL PuPS Program will comply with ASME IX for each of them.

During this qualification, specially fabricated ASME Test Lids, fabricated to Rocky Flats Drawing Number 51604-4426, will be welded to standard 3013 Outer Cans to allow tensile and bend testing of the weld area as required by ASME IX. Only one configuration of process variables will be qualified at this time. Each test part will be assembled and 0.002-inthick feeler gage stock will be used to ensure a 0.002-in. gap, a condition that exceeds the maximum gap condition expected in production. 


\section{LLNL PUPS WELD QUALIFICATION PLAN}

Before welding the ASME IX test parts, part rotation speed and weld power to the workpiece, both ASME essential variables, will be measured to verify they are within the requirements shown in Appendix 3. The plume jet location will also be verified by checking the plume jet reference dimension. The plume jet reference dimension is the distance between the leading edge of the plume jet adjusting bracket and the leading edge of the barrel bracket as shown in BNFL Drawing OBE 15555803.

ASME test welds will be visually, radiographically, and metallographically examined according to the requirements in Appendix 2. Specimens will then be machined from test welds to conduct tensile and bend tests using ASME IX procedures. The final result of these tests will be a Procedure Qualification Record (PQR) for the single configuration of welding parameters and a Welding Procedure Specification (WPS) showing the allowed range of each essential parameter that has been ASME qualified.

Each operator who welds an acceptable ASME IX test part will be ASME IX qualified, and a Welder/Welding Operator Performance Qualification (WPQ) form will be completed to document it.

SRS will review and concur with the WPS. LLNL will be provided the welding WPQs to SRS.

\subsection{Twenty Five- Dummy Outer Can Verification Run}

\subsubsection{Welding}

After the ASME qualification of the process and operators, a 25 dummy Outer Can (DOC) verification run will be performed. The DOC test welds uses a normal 3013 Outer Can Lid welded to an Outer Can. Each DOC will contain a mockup of the Inner Can, with surrogate material, to replicate the approximate size, volume, and weight of a production Inner Can. Each surrogate Inner Can will be filled with approximately $5 \mathrm{Kg}$ of surrogate materials. Each surrogate Inner Can will be used with multiple dummy Outer Cans. Each DOC will be processed using the exact same production procedures so that these welds are as close as possible to production joints.

\subsubsection{Examination}

Each DOC will be leak checked and then visuually, radiographically and metallographically examined. Metallographic sections will be taken as specified in Appendix 2. The requirements for each of the above tests and examinations are given in Appendix 2.

The results of the 25 can process verification (radiographs, micrographs, etc.) will be sent to SRS for review and approval before the production run of Outer Cans is started. 


\section{LLNL PUPS WELD QUALIFICATION PLAN}

\subsection{Empty Outer Can Weld Tests}

For the 25 DOC Verification Run and the 1-in-25 lot qualification, each DOC is required by SRS to contain a mockup of the Inner Can to replicate the approximate size, volume, and weight of a production Inner Can. Because of the logistical difficulties anticipated with handling and verifying DOCs filled with surrogate material in a secured plutonium area. LLNL may use Empty Outer Cans (EOCs) for additional weld tests, process troubleshooting, and operator qualification.

EOCs will use a 3013 Outer Can lid welded to a 3013 Outer Can. A hole predrilled through the bottom or cylindrical wall to expedite removal from the Radioactive Managament Area (RMA) is optional. Each test can will be welded using the same parameters as production assemblies (unless a special test is being conducted using other parameters). EOCs will be examined to the same requirements as DOCs.

Prior to using EOCs, at least 2 EOCs will be welded and tested like the DOCs mentioned above to verify that this test is representative of welds made in DOCs.

\subsection{Process Control and Verification During Production}

The activities described below will ensure control and verification of the Inner Can weld/cut processes and Outer Can weld process during production.

\subsection{DOC Process Sample Welding}

Process monitoring of Outer Can Welds will be conducted by periodically welding and evaluating DOC tests samples. The results of each test sample will be sent to the SRS Design Authority to qualify for acceptance of a maximum 24 previously welded production assemblies. After the first 100 successful production cans, LLNL, with SRS concurrance, may review and change the frequency of the dummy can duration.

The same process data will be recorded for DOC test welds as are recorded for production welds, and each test weld will be leak tested and visually examined the same as production welds. In addition, each test weld will be radiographically and metallographically examined to the requirements of Appendix 2. The results will be tracked to determine process trends and when corrective action should be taken.

\subsection{Periodic Variable Verification}

There are a number of welding parameters that are not measured during each production weld. These are not expected to change because they are maintained by physical controls in the system. These parameters will be checked periodically to verify that the have not changed. These parameters are the laser power and rotational speed. 


\section{LLNL PuPS WELD QUALIFICATION PLAN}

\subsubsection{Control of Laser Power.}

Weld power to the workpiece is the one ASME-essential variable that is expected to change during production. As the laser flashlamps are used, they slowly deteriorate and the laser output gradually becomes less with time. Therefore, Lumonics, Ltd, the manufacture of the laser, provides a "\% Pcal" setting which the user periodcally adjusts to compensate for this gradual reduction.

To determine when an adjustment of \%Pcal is needed, PuPS Operators will monitor the weld as follows:

1) During each production Inner Can Weld, Inner Can cut, and Outer Can weld, the operator will record the laser generated power output of the laser from the Multiwave software. This value is correlated to the delivered power level given in Appendix 3. Appendix 3 shows the recommended power levels for the Inner Can weld, cut and Outer Can Weld. If the correlated delivered laser power level falls outside of these ranges, the PuPS operator will perform a Weld Power Probe Test. The test measures the power delivered by the laser to the workpiece using a commercial calorimeter designed specifically for measuring laser power. During this test, the \% Pcal setting of the laser will be adjusted as needed to achieve the nominal power that has been qualified. Changes in the \%Pcal will be documented per the LLNL configuration control procedures. The correlation between the generated and delivered power will be confirmed at this time.

2) At the beginning of each production day, PuPS Operators will conduct a "Powerat-Laser" test using the laser weld power demand settings. This test operates the laser with the shutter closed. The power is monitored by connecting the laser output signal to a laptop computer and reading the value from the computer screen. This value is correlated to the delivered power level given in Appendix 3. If thecorrelated value recorded from the Power-at-Laser test falls outside the recommended value range shown in Appendix 3 it will also "trigger" the scheduling of a Weld Power Probe Test, and the same procedure for changing the $\%$ Pcal setting described above will be followed.

3) A Weld Power Probe Test will be conducted at least once every 2 calender months of operation or after maintenance is done which could affect this variable, even if none of the above "trigger" events has caused the scheduling of this test. The dates and results of each Weld Power Probe Test will be tracked to assure that the laser power requrements are meet. This test will be used to develop the correlation between generated power and delivered power. 


\section{LLNL PUPS WELD QUALIFICATION PLAN}

\subsubsection{Stepper Motor}

Because the rotation speeds of the Inner Can weld, Inner Can cut, and Outer Can weld is controlled by stepper motors, they are not expected to drift from the nominal values. A failure of the motor controller will cause complete stoppage of the system. Periodic DOC Process Sample welds will verify that all variables (including rotation speed) are normal. Also the rotation speed of the stepper motors will be verified once every 2 calender months of operation or after maintenance is done which could affect this variable.

\subsection{Rules for Part Rejection and Work Stoppage}

Appendix 3 gives "essential ranges" and recommended ranges for a number of welding parameters. Falling outside of these ranges requires the following actions:

1) If any of the variables fall outside of the "essential range" the production assembly will be rejected and corrective actions will be taken.

2) If the daily Power-at-Laser Test result falls outside the "essential range," production welding will be stopped until corrective action is taken and/or a Weld Power Probe Test is conducted.

3) If the results of the Outer Can Power Probe Test is outside the "essential range". All production assemblies will be rejected that have been welded since the most recent of (a) an acceptable DOC Process Sample Weld, or (b) a Power Probe Test result within the "essential range". After corrective measures have been taken, a EOC or DOC will be processed and examined as described in Section 4.1. If the examinations are acceptable, production welding will commence. LLNL may, at its own risk, start production welding after corrective measures are taken but prior to obtaining the examination results on the EOC or DOC. If the EOC or DOC examinations are acceptable, all production assemblies welded in the time interval are acceptable. If the EOC or DOC examinations are unacceptable, all production assemblies welded in the time interval are also rejected. Further corrective measures will then be taken and another EOC or DOC will be processed and examined until the results are acceptable prior to restarting production welding.

4) If production welding is stopped due to PuPS equipment problems that affect weld quality (different than that above) or if a condition or conditions observed during production welding that indicate a change in the normal operationof the PuPS (e.g., melted shield gas shoe, plume jet position change, stepper motor problems, etc.) that affects weld quality, an EOC or DOC shall be processed prior to correcting the problem to determine the acceptability of all prior cans in the lot. This EOC or DOC will be examined as described In Section 4.1. Prior to resuming production welding, the following is required; corrective measures have been taken; an EOC or DOC will be processed and examined as described above. If the examinations are acceptable, 


\section{LLNL PUPS WELD QUALIFICATION PLAN}

production welding will commence. If the examination are unacceptable, further corrective measures will be taken and another EOC or DOC will be processed and examined until the results are acceptable prior to restarting production welding.

\subsection{Equipment Maintenance and Repair}

Routine maintenance and cleaning of the laser heads and fixturing will be done to ensure continued proper operation. A list of these items is shown below with the frequency of each maintenance item. The frequency may be adjusted as experience is gained with the equipment

\begin{tabular}{|l|l|}
\hline Maintenance Item & Frequency \\
\hline $\begin{array}{l}\text { 1) Outer Can Weld Plume Control Nozzle Inspection and Cleaning } \\
\text { (Includes checking position after cleaning) }\end{array}$ & 3 Months \\
\hline $\begin{array}{l}\text { 2) Outer Can Weld Shielding Shoe Removal and Maintenance } \\
\text { (Includes checking position after cleaning) }\end{array}$ & 3 Months \\
\hline 3) Outer Can Weld Coverglass Cleaning and Replacement & 3 Months \\
\hline 4) Outer Can Weld Laser Head Height Check and Adjustment & 6 Months \\
\hline $\begin{array}{l}\text { 5) Inner Can Weld/Cut Shielding Shoe Removal and Maintenance } \\
\text { (Includes checking position after cleaning) }\end{array}$ & 3 Months \\
\hline 6) Inner Can Weld Coverglass Cleaning and replacement & 3 Months \\
\hline 7) Inner Can Weld Laser Head Height Check and Adjustment & 6 Months \\
\hline 8) Inner Can Cut Coverglass Cleaning and replacement & 3 Months \\
\hline 9) Inner Can Cut Laser Head Height Check and Adjustment & 6 Months \\
\hline
\end{tabular}

Prior to maintenance an EOC or DOC will be run to verify that production cans before maintenance are acceptable. An EOC or DOC will also be run after maintenance to verify the system has been returned to production mode successfully. The EOC or DOC will be examined as described in Section 4.1.

\subsection{Data Collection}

Data collected for the PuPS program includes process variable values, leak test rates, and visual examination results for all production welds and periodic sample welds (EOC and DOC welds). In addition, the EOC and DOC test welds will be evaluated by radiography and metallography. The EOC and DOC are those described in Sections 3.2, 3.3, 4.1, 4.2, 4.3, and 4.4. Also the power to the workpiece and can rotation speed will be verified periodically.

A summary of the data to be collected and the frequncy of collection are shown in Appendix 3. This appendix also shows the acceptance requirements for each process variable test and examination. A column titled "essential range" shows those requirements that are necessary for the acceptance of production assemblies. An "NA" in this column indicates that the measurement is not required for product acceptance. A column titled "recommended range" shows a non-binding recommended value for the measurement. When values consistently fall outside this range corrective action will be taken. 


\section{LLNL PUPS WELD QUALIFICATION PLAN}

The following paragraphs describe the general methods to be used for data collection.

1. Weld Process Variables

Each production Outer Can weld will be done by an ASME IX-qualified welding operator. The data for the Inner Can weld, Inner Can cut, and Outer Can weld will be collected on run sheets. Laser power will be recorded off of the Multiwave software. All helium flows and pressures will be read from the appropriate meters on the gas panels. These values will be recorded by the operator.

2. Visual Examination The weld face (visible outside surface) of all welded 3013 Outer Cans and Inner Cans will be visually examined at a magnification of at least $7 \mathrm{X}$ to the requirements included in Appendix 2.

3. Power-At-Laser Test

Before each weld, PuPS Operators will conduct a "Power-at-Laser" testing of the laser power demand setting. This test operates the laser with the shutter closed. The power is monitored by connecting the laser output signal to a laptop computer and reading the value from the computer screen. This test will be conducted under the direction of an authorized PuPS operator. This is done as part of the warmup of the laser prior to welding.

4. Radiographic Examination

EOC and DOC welds will be examined per ASME Section VIII, Division 1, UW-51. Porosity requirements are described in ASME Section VIII Appendix 4. These examinations will be performed by personnel certified in radiography to ASNT SNT-TC1A Level II or higher. Film interpretation will be performed by personnel certified ASNT SNT-TC-1A Level III minimum in radiography.

5. Metallographic Examination

EOC and DOC welds will be sectioned transverse to the travel direction and metallographically examined in at least 4 locations including the slope-in area. A photomicrograph at a minimum $20 \mathrm{X}$ magnification will be used to measure and record penetration, width, undercut, porosity, linear indications, and lack-of-fusion.

6. Power Probe Tests

At least every 2 months of operation, power to the work piece will be measure for all 3 laser processes. This will be done using a commercial calorimeter type power probe placed below the laser head being measured. Several tests will be done to ensure repeatability. This test will be conducted under the direction of an authorized PuPS operator.

7. Can Rotation Speed Variation Test 


\section{LLNL PUPS WELD QUALIFICATION PLAN}

At least every 2 months of operation, the rotation speed of the stepper moters will be verified by measuring the time of one or more revolutions using a stopwatch with the laser inactive. This test will be conducted under the direction of an authorized PuPS Operator.

\subsection{Process Control}

Process control will be implemented to ensure that the PuPS weld processes remain in control. The data collected will be tracked by control charts and other appropriate means. The data will be trended to determine when it is approaching the limits stated in Appendix 3.

\subsection{System Variables}

During qualification, documentation will be provided to the SRS Design Authority defining the condition of key system variables. These variables will not be changed during production without approval of SRS. A complete list of key variables will be made by a joint agreement between LLNL and SRS. The following is a partial list of system variables that will be documented:

1) PuPS equipment drawings and revision numbers

2) Software revisions

3) 3013 component drawings and revision numbers

4) 3013 material (lot number, ASME specification number, type or grade, UNS number, $P$ number, group number, and minimum tensile strength)

5) Welding Procedure Specifications,

6) Accompanying Procedure Qualification Records.

\subsection{References}

1) DOE STD 3013-00, "Stabilization, Packaging, and Storage of Plutonium Bearing Materials, U.S. Department of Energy, 2000.

2) SRS Acceptance Specification, "Savannah River Site Stabilization and Packaging Requirements for Plutonium Bearing Materials for Storage," G-ESD-00035, Rev. 1, July 26, 2000 .

3) DOE Order 440.1A, "Worker Protection Management for DOE Federal and Contractor Employees," U.S. Department of Energy, March 27, 1998.

4) ASME VIII, ASME Boiler and Pressure Vessel Code Section VIII, Div. 1( Rules for Construction of Pressure Vessels), 1998

5) ASME IX, ASME Boiler and Pressure Vessel Code Section IX (Qualification Standard for Welding and Brazing Procedures, Welders, Brazers, and Welding and Brazing Operators), 1998 


\section{LLNL PUPS WELD QUALIFICATION PLAN}

6) ASME V, ASME Boiler and Pressure Vessel Code Section V (Nondestructive Examination), 1998 


\section{LLNL PUPS WELD QUALIFICATION PLAN}

Appendix 1: PuPS ASME IX Weld Qualification Compliance Matrix

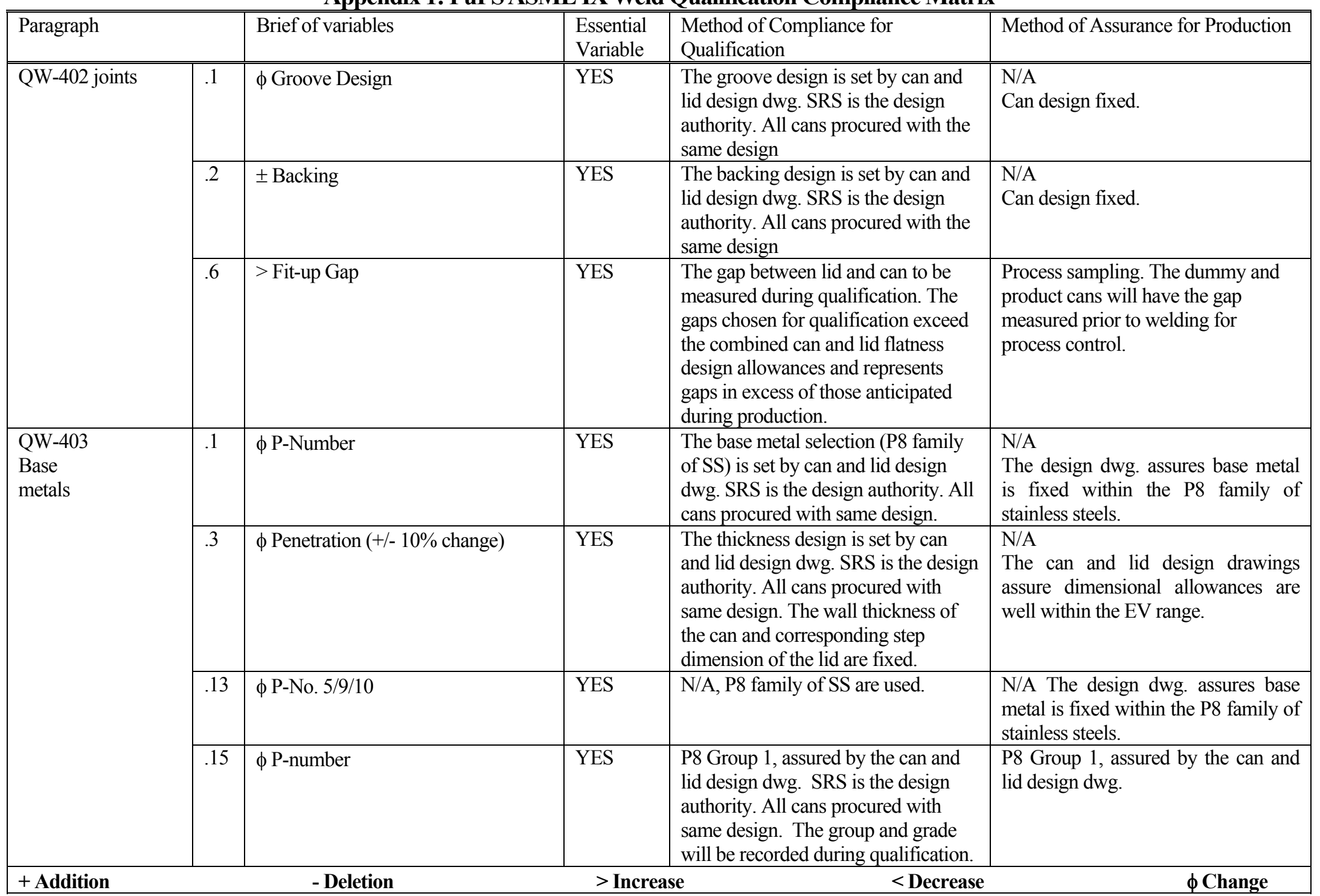




\section{LLNL PUPS WELD QUALIFICATION PLAN}

Appendix 1. PuPS ASME IX Weld Qualification Compliance Matrix (continued)

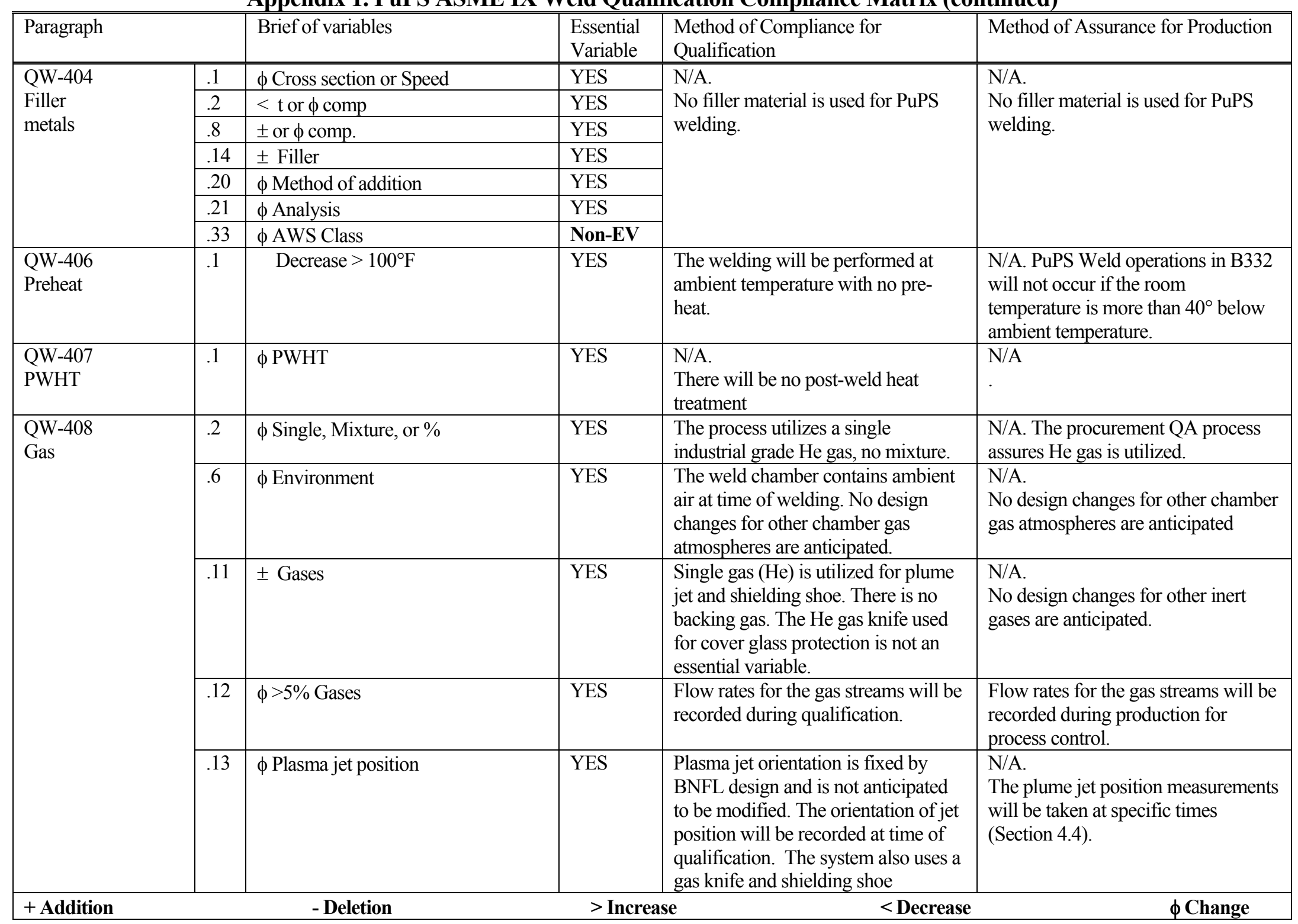




\section{LLNL PUPS WELD QUALIFICATION PLAN}

Appendix 1. PuPS ASME IX Weld Qualification Compliance Matrix (continued)

\begin{tabular}{|c|c|c|c|c|c|}
\hline \multicolumn{2}{|l|}{ Paragraph } & Brief of variables & $\begin{array}{l}\text { Essential } \\
\text { Variable }\end{array}$ & $\begin{array}{l}\text { Method of Compliance for } \\
\text { Qualification }\end{array}$ & Method of Assurance for Production \\
\hline \multirow[t]{5}{*}{$\begin{array}{l}\text { QW-409 } \\
\text { Electrical } \\
\text { Characteristics }\end{array}$} & .19 & $\phi$ Pulse & 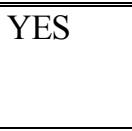 & $\begin{array}{l}\text { N/A. The Lumonics } 2000 \text { laser } \\
\text { system is continuous wave. }\end{array}$ & $\begin{array}{l}\text { N/A. Controlled by equipment } \\
\text { design. The Lumonics system is not } \\
\text { anticipated to change. }\end{array}$ \\
\hline & .20 & $\phi$ Mode, energy & YES & $\begin{array}{l}\text { N/A. The Lumonics } 2000 \text { laser } \\
\text { system is gaussian. }\end{array}$ & $\begin{array}{l}\text { N/A. Controlled by equipment } \\
\text { design. The Lumonics system is not } \\
\text { anticipated to change }\end{array}$ \\
\hline & .21 & $\phi$ Power, speed, d/fl, distance & YES & $\begin{array}{l}\text { Power-The power at the work piece } \\
\text { will be recorded at time of } \\
\text { qualification utilizing calibrated } \\
\text { power pucks. The laser settings will } \\
\text { be recorded for information. } \\
\text { Maximum variation allowed is } 5 \% \\
\text { Speed - The can rotational speed will } \\
\text { be recorded at time of qualification. } \\
\text { The maximum variation allowed is } \\
2 \% \text {. }\end{array}$ & $\begin{array}{l}\text { Power - The power at the work piece } \\
\text { will be recorded at specific times } \\
\text { (Section 4.2.1.3) for process control } \\
\text { utilizing calibrated power probes. } \\
\text { The laser settings will be recorded for } \\
\text { information trending. } \\
\text { Speed - N/A. The can speed is } \\
\text { controlled by equipment design. } \\
\text { This will also be checked at specific } \\
\text { times (Section 4.2.2) }\end{array}$ \\
\hline & & & & $\begin{array}{l}\text { Beam Dia./Focal length - The beam } \\
\text { diameter and focal length settings } \\
\text { will be recorded at time of } \\
\text { qualification. The maximum } \\
\text { variation is } 2 \% \text {. }\end{array}$ & $\begin{array}{l}\text { Beam Dia./Focal length - fixed by } \\
\text { lens. }\end{array}$ \\
\hline & & & & $\begin{array}{l}\text { Distance - The distance from the } \\
\text { weld head to the can is controlled by } \\
\text { fixture design. The distance will be } \\
\text { recorded at time of qualification. The } \\
\text { maximum variation is } 2 \% \text {. }\end{array}$ & $\begin{array}{l}\text { Distance-The distance from the } \\
\text { weld head to the can is controlled by } \\
\text { fixture design. The distance will be } \\
\text { recorded at specific times (Section } \\
\text { 4.4) }\end{array}$ \\
\hline \multicolumn{2}{|l|}{ + Addition } & - Deletion & \multicolumn{2}{|c|}{$>$ Increase } & $\phi$ Change \\
\hline
\end{tabular}




\section{LLNL PUPS WELD QUALIFICATION PLAN}

Appendix 1. PuPS ASME IX Weld Qualification Compliance Matrix (continued)

\begin{tabular}{|c|c|c|c|c|c|}
\hline \multicolumn{2}{|l|}{ Paragraph } & \multirow{2}{*}{$\begin{array}{l}\text { Brief of variables } \\
\phi \text { Method of cleaning }\end{array}$} & \multirow{2}{*}{$\begin{array}{l}\text { Essential } \\
\text { Variable } \\
\text { Non - EV }\end{array}$} & \multirow{2}{*}{$\begin{array}{l}\text { Method of Compliance for } \\
\text { Qualification } \\
\text { Although not an EV, the method of } \\
\text { cleaning will be recorded during } \\
\text { qualification. }\end{array}$} & \multirow{2}{*}{$\begin{array}{l}\text { Method of Assurance for Production } \\
\begin{array}{l}\text { The method of cleaning will be } \\
\text { included in the PuPS welding } \\
\text { guidance. }\end{array}\end{array}$} \\
\hline \multirow[t]{7}{*}{$\begin{array}{l}\text { QW-410 } \\
\text { technique }\end{array}$} & 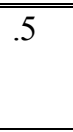 & & & & \\
\hline & .7 & $\phi$ Oscillation & YES & $\begin{array}{l}\text { N/A. The Lumonics } 2000 \text { laser } \\
\text { system is stationary beam. A } \\
\text { statement to this effect will be added } \\
\text { to the weld qualification } \\
\text { documentation }\end{array}$ & $\begin{array}{l}\text { N/A. Controlled by equipment } \\
\text { design. The Lumonics system is not } \\
\text { anticipated to change }\end{array}$ \\
\hline & .14 & $\phi$ Angle of beam axis & YES & $\begin{array}{l}\text { The angle of the beam axis is fixed } \\
\text { by fixture design. A sketch will be } \\
\text { recorded during qualification period } \\
\text { to display orientation. }\end{array}$ & $\begin{array}{l}\text { N/A. The angle will be verified as } \\
\text { unchanged as defined in Section 4.4. }\end{array}$ \\
\hline & .17 & $\phi$ Type of equipment & YES & $\begin{array}{l}\text { The Lumonics } 2000 \text { laser system will } \\
\text { be used for qualification. A statement } \\
\text { to this effect will be added to the } \\
\text { weld qualification documentation }\end{array}$ & $\begin{array}{l}\text { N/A. Controlled by equipment } \\
\text { design. The Lumonics system is not } \\
\text { anticipated to change }\end{array}$ \\
\hline & .20 & + Wash pass & YES & $\begin{array}{l}\text { The automated welding program } \\
\text { does not utilize a wash pass. A } \\
\text { statement to this effect will be added } \\
\text { to the weld qualification } \\
\text { documentation }\end{array}$ & $\begin{array}{l}\text { N/A. Controlled by process design. } \\
\text { The automated weld program is not } \\
\text { anticipated to change. }\end{array}$ \\
\hline & .21 & 1 vs. 2 side welding & YES & $\begin{array}{l}\text { The automated welding program, } \\
\text { fixturing design, can design, and } \\
\text { process design utilizes single side } \\
\text { weld. A statement to this effect will } \\
\text { be added to the weld qualification } \\
\text { documentation }\end{array}$ & $\begin{array}{l}\text { N/A. Controlled by process design. } \\
\text { The automated weld program is not } \\
\text { anticipated to change. }\end{array}$ \\
\hline & .37 & $\phi$ Single to multi pass & YES & $\begin{array}{l}\text { The automated welding program } \\
\text { does not incorporate a multi-pass } \\
\text { weld process. An overlap is utilized } \\
\text { to assure complete weld coverage. A } \\
\text { statement to this effect will be added } \\
\text { to the weld qualification } \\
\text { documentation }\end{array}$ & $\begin{array}{l}\text { N/A. Controlled by process design. } \\
\text { The automated weld program is not } \\
\text { anticipated to change. }\end{array}$ \\
\hline + Addition & & - Deletion & $>$ Incre: & $<$ Decrease & $\phi$ Change \\
\hline
\end{tabular}




\section{LLNL PUPS WELD QUALIFICATION PLAN}

\section{Appendix 2: PuPS Inspection and Test Requirements}

\subsection{Outer Can Weld}

\subsection{Visual Examination at $7 \mathrm{X}$ min.}

\subsubsection{Minimum weld face width shall be 0.075 in.}

a) Source: The weld widths of the first 29 of the 60 -can Broomfield run ranged from 0.085 in. to $0.135 \mathrm{in}$. The average was $0.1136 \mathrm{in}$. with a standard deviation of $0.0136 \mathrm{in}$. The acceptance requirement is the average minus 3 standard deviations.

b) This will be reevaluated as part of the 25 -can verification run.

\subsubsection{Weld face centerline-to-lid-edge shall be $0.1575 \pm 0.010$ in.}

a) The variation of this value observed in the 25 -can verification welds will be used to establish a tolerance requirement.

b) Source: The nominal distance from the edge of the lid to the weld-parting plane is 0.1575 in. Metallographic examination of cans made during the Broomfield 60-can run has shown that the centerline of the weld face is offset from the centerline of the weld root by an average of 0.0075 in. toward the lid edge. Early results from B371 weld examinations indicate less offset than experienced in Broomfield. Therefore, measurements of the weld face and weld root centerlineto-lid-edge will be made on the verification cans and used to determine process control value.

1.1.3 The weld surface shall be free of voids $>0.030 \mathrm{in}$. dia.

a) Source: ASME VIII Section UW-51 (b) 4 and Appendix 4 specify that no voids $>0.030 \mathrm{in}$. (1/4 of the section thickness) be detected by radiographic examination. We will not radiograph these joints in production, but will apply the same porosity standard to the weld surface.

\subsubsection{The weld surface shall show no evidence of lack of fusion or cracks.}

\subsubsection{Weld undercut shall not exceed 0.012 inch.}

a) Source: ASME VIII Section UW-35.

\subsection{Helium Leak Check}

\subsubsection{The helium leak rate shall be below $1 \times 10^{-7} \mathrm{std} \mathrm{cm}^{3} / \mathrm{sec}$.}

a) Source: DOE-STD-3013-00 Section A.6.2.3.2

\subsection{Radiographic Examination}

Each Empty Outer Can (EOC) or Dummy Outer Can (DOC) shall be examined by $100 \%$ radiography per UW-51 of ASME Section VIII, Division 1. The radiographic film shall be interpreted by personnel who are Level III certified in radiography per the American Society for Nondestructive Testing, Inc. (ASNT) "Recommended Practice for Nondestructive Testing Personnel Qualification and Certification," SNT-TC$1 \mathrm{~A}$. 


\section{LLNL PUPS WELD QUALIFICATION PLAN}

\subsection{Metallographic Examination}

\subsubsection{Can Sectioning}

Each Empty Outer Can or Dummy Outer Can weld will be sectioned transverse to the weld direction in at least four (4) locations to include one at the weld tie-in, one in the overlap area, one in the body of the weld, and one at the weld stop-start area.

(Source SRS 1.d)

\subsubsection{Sample Examination}

Each cross section will be suitable etched and photographed at a minimum of $20 \mathrm{X}$ magnification. The weld and heat-affected zone shall be examined to ensure complete penetration of the joint and freedom from cracks and lack of fusion. (Source SRS 1.d)

\subsubsection{Minimum weld penetration shall be 0.118 in. (to the step).}

a) Source: ASME VIII Section UW-13, Figure UW-13.2d requires a full penetration weld.

1.4.4 The weld surface shall be free of voids $>0.030 \mathrm{in}$. dia.

a) Source: ASME VIII Section UW-51 (b) 4 and Appendix 4 specify that no voids $>0.030 \mathrm{in}$. (1/4 of the section thickness) be detected by radiographic examination. This criterion is for detection by radiographic examination, we are choosing to apply the same standard to the metallographic examinations also.

1.4.5 The $a+b / 2$ ts ratio must be 1.00 or greater.

a) Source: ASME VIII Section UW-13, Figure UW-13.2d requires a full penetration weld.

\subsubsection{The weld surface shall show no evidence of lack of fusion or cracks.}

\subsubsection{Weld thickness reduction shall not exceed 0.012 in.}

a) Source: ASME VIII Section UW-35b2 requires that weld thickness reduction shall not exceed $10 \%$ of the section thickness.

\subsection{Inner Can Weld}

\subsection{Visual Examination at $7 \mathrm{X}$ min.}

2.1.1 The weld shall show complete fusion around the circumference, be free of cracks and surface porosity.

a) Source: DOE-STD-3013-00 requires the weld to be leak tight. This implies that the weld has complete fusion around the circumference, and no through the wall cracks or porosity. These examinations are for process monitoring only.

\subsection{Helium Leak Check}

2.2.1 The helium leak rate shall be below $1 \times 10^{-7} \mathrm{std}^{3} / \mathrm{sec}$.

a) Source: DOE-STD-30130-00 Section A.6.2.3.2

\subsection{Surface Contamination}

2.3.1 The exterior of the Inner Can shall not exceed $2000 \mathrm{dpm} / 100 \mathrm{~cm}^{2}$.

a) Source: DOE-STD-3013-00 Section 6.2.4.2 


\section{LLNL PUPS WELD QUALIFICATION PLAN}

\section{Appendix 3: LLNL PuPS Data Collected for Laser Weld Process Control}

\begin{tabular}{|c|c|c|c|c|}
\hline Frequency & Process or Procedure & Measured Item & Essential Range & Recommended Range \\
\hline \multirow{22}{*}{$\begin{array}{l}\text { Every } \\
\text { Production } \\
\text { Weld }\end{array}$} & \multirow[t]{22}{*}{ PuPS Operation Inner Can Weld } & Date & Required Data & Required Data \\
\hline & & \begin{tabular}{|l|} 
Operator's Name \\
\end{tabular} & Required Data & Required Data \\
\hline & & Assistant's Name & NA & Optional \\
\hline & & Can Tare Weight(s) & Required Data & Required Data \\
\hline & & Can Net Weight(s) & Required Data & Required Data \\
\hline & & Convenience Can LOI(s) & Required Data & Required Data \\
\hline & & Verified Gross Weight(s) & Required Data & Required Data \\
\hline & & Calculated Weight Gain(s) & $<0.1 \mathrm{~g}$ & $<0.1 \mathrm{~g}$ \\
\hline & & Inner Can Number & Required Data & Required Data \\
\hline & & Bung Number & Required Data & Required Data \\
\hline & & Helium Purge Pressure & NA & $>2$ psig \\
\hline & & Helium Purge Flow & NA & $0.9 \mathrm{~m}^{3} / \mathrm{hr}$ \\
\hline & & $\begin{array}{l}\text { Delivered Inner Can Weld } \\
\text { Laser Power }\end{array}$ & NA & 1378-1450-1522 Watts \\
\hline & & Helium Weld Purge Flow & NA & $6.7-\underline{7.0}-7.3 \mathrm{~m}^{3} / \mathrm{hr}$ \\
\hline & & Shielding Shoe Pressure & NA & 35- 37- 38.5 psig \\
\hline & & Shielding Shoe Flow & NA & $20-\underline{\mathbf{2 1}}-\quad 22 \mathrm{~m}^{3} / \mathrm{hr}$ \\
\hline & & $\begin{array}{l}\Delta \mathrm{P} \text { Before Weld } \\
\text { (Cupboard to Room) }\end{array}$ & NA & NA \\
\hline & & $\begin{array}{l}\Delta \mathrm{P} \text { Before Weld } \\
\text { (Glovebox to Cupboard) }\end{array}$ & NA & NA \\
\hline & & $\begin{array}{l}\Delta \mathrm{P} \text { During Weld } \\
\text { (Cupboard to Room) }\end{array}$ & NA & NA \\
\hline & & $\begin{array}{l}\Delta \mathrm{P} \text { During Weld } \\
\text { (Glovebox to Cupboard) }\end{array}$ & NA & $<-.5^{\prime \prime} \mathrm{wg}$ \\
\hline & & $\begin{array}{l}\text { Delivered Inner Can Cut Laser } \\
\text { Power }\end{array}$ & NA & $1568-1650-1732$ Watts \\
\hline & & Co-Axial Head Pressure & NA & 67-70-74 psig \\
\hline
\end{tabular}




\section{LLNL PUPS WELD QUALIFICATION PLAN}

Appendix 3: LLNL PuPS Data Collected for Laser Weld Process Control (continued)

\begin{tabular}{|c|c|c|c|c|}
\hline Frequency & Process or Procedure & Measured Item & Essential Range & Recommended Range \\
\hline \multirow{8}{*}{$\begin{array}{l}\text { Every } \\
\text { Production } \\
\text { Weld }\end{array}$} & \multirow{8}{*}{$\begin{array}{l}\text { PuPS Inner Can Weld and Cut } \\
\text { Inspection }\end{array}$} & Weld Fusion & Complete & Complete \\
\hline & & Leak Rate & $<1 \times 10^{-7} \mathrm{std} \mathrm{cc} / \mathrm{sec} \mathrm{He}$ & $<1 \times 10^{-7}$ std cc/sec He \\
\hline & & Leak Time & NA & $<5$ minutes \\
\hline & & Total Contamination & $<500 \mathrm{dpm} \alpha / 100 \mathrm{~cm}^{2}$ & $<500 \mathrm{dpm} \alpha / 100 \mathrm{~cm}^{2}$ \\
\hline & & Dose Rate @ contact & Required Data & Required Data \\
\hline & & Dose Rate @30 cm & Required Data & Required Data \\
\hline & & Dose Rate @30 cm & Required Data & Required Data \\
\hline & & Final Gross Weight & Required Data & Required Data \\
\hline
\end{tabular}




\section{LLNL PUPS WELD QUALIFICATION PLAN}

Appendix 3: LLNL PuPS Data Collected for Laser Weld Process Control (continued)

\begin{tabular}{|c|c|c|c|c|}
\hline Frequency & Process or Procedure & Measured Item & Essential Range & Recommended Range \\
\hline \multirow{28}{*}{$\begin{array}{l}\text { Every } \\
\text { Production } \\
\text { Weld }\end{array}$} & \multirow[t]{14}{*}{ PuPS Operation Outer Can Weld } & Date & Required Data & Required Data \\
\hline & & Operator's Name & Required Data & Required Data \\
\hline & & Assistant's Name & NA & Optional \\
\hline & & Inner Can Gross Weight & Required Data & Required Data \\
\hline & & Outer Can Number & Required Data & Required Data \\
\hline & & Lid Number & Required Data & Required Data \\
\hline & & Gap Measurement & $\leq 0.002$ in & $\leq 0.0015$ in \\
\hline & & $\begin{array}{l}\text { Delivered Outer Can Weld } \\
\text { Laser Power }\end{array}$ & 1626-1712-1798 Watts & 1644-1712-1780 Watts \\
\hline & & Purge Head Pressure & $5.7-\quad \underline{6.0}-$ & $5.7-\quad \underline{6.0-}$ \\
\hline & & Purge Head Flow & 95- $\quad \underline{\mathbf{1 0 0}-} \quad 105 \mathrm{lpm}$ & $95-\underline{100-}$ \\
\hline & & Shield Shoe Pressure & $5.7-\quad \underline{6.0}-$ & $5.7-\quad \underline{6.0}-$ \\
\hline & & Shield Shoe Flow & $\begin{array}{lll}76- & \mathbf{8 0 -} & 84 \mathrm{lpm}\end{array}$ & $76-\quad \underline{\mathbf{8 0 -}} \quad 84 \mathrm{lpm}$ \\
\hline & & Plasma Plume Pressure & 5.7- $\underline{\mathbf{6 . 0}}-6.3$ bar & $5.7-\quad \underline{6.0-}$ \\
\hline & & $\Delta \mathrm{P}$ (cupboard to room) & NA & $<-0.5^{\prime \prime} \mathrm{wg}$ \\
\hline & \multirow[t]{14}{*}{ PuPS Outer Can Weld Inspection } & "Weld Width & $\geq 0.075$ in. & $\geq 0.075$ in. \\
\hline & & Weld C.L.-to-edge dimension & $0.1575 \pm 0.010$ in. & $0.1575 \pm 0.010$ in. \\
\hline & & Voids & None $>0.030$ & None $>0.030$ \\
\hline & & Cracks & None Allowed & None Allowed \\
\hline & & Weld Undercut & $<0.012$ in & $<0.012$ in \\
\hline & & Leak Rate & $<1 \times 10^{-7}$ std cc/sec He & $<1 \times 10^{-7}$ std cc/sec He \\
\hline & & Leak Time & NA & $<5$ minutes \\
\hline & & Removable Contamination & $<20 \mathrm{dpm} \alpha / 100 \mathrm{~cm}^{2}$ & $<20 \mathrm{dpm} \alpha / 100 \mathrm{~cm}^{2}$ \\
\hline & & Total Contamination & $<500 \mathrm{dpm} \alpha / 100 \mathrm{~cm}^{2}$ & $<500 \mathrm{dpm} \alpha / 100 \mathrm{~cm}^{2}$ \\
\hline & & Dose Rate $\gamma @$ contact & Required Data & Required Data \\
\hline & & Dose Rate $\gamma @ 30 \mathrm{~cm}$ & Required Data & Required Data \\
\hline & & Dose Rate $\eta @$ contact & Required Data & Required Data \\
\hline & & Dose Rate $\eta @ 30 \mathrm{~cm}$ & Required Data & Required Data \\
\hline & & Final Gross Weight & Required Data & Required Data \\
\hline
\end{tabular}




\section{LLNL PUPS WELD QUALIFICATION PLAN}

Appendix 3: LLNL PuPS Data Collected for Laser Weld Process Control (continued)

\begin{tabular}{|c|c|c|c|c|}
\hline Frequency & Process or Procedure & Measured Item & Essential Range & Recommended Range \\
\hline \multirow{28}{*}{$\begin{array}{l}\text { Empty } \\
\text { Outer Can } \\
\text { (EOC) or } \\
\text { Dummy } \\
\text { Outer Can } \\
\text { (DOC) } \\
\text { Test Weld: } \\
1 \text { in } 25 \\
\text { Production } \\
\text { Welds. }\end{array}$} & \multirow{15}{*}{ PuPS Operation Outer Can Weld } & Date & Required Data & Required Data \\
\hline & & Operator's Name & Required Data & Required Data \\
\hline & & Assistant's Name & NA & Optional \\
\hline & & Inner Can Number & Required Data & Required Data \\
\hline & & Inner Can Gross Weight & Required Data & Required Data \\
\hline & & Outer Can Number & Required Data & Required Data \\
\hline & & Lid Number & Required Data & Required Data \\
\hline & & Gap Measurement & $<0.002$ in & $<0.0015$ in \\
\hline & & $\begin{array}{l}\text { Delivered Outer Can Weld } \\
\text { Laser Power }\end{array}$ & 1626-1712-1798 Watts & 1644-1712-1780 Watts \\
\hline & & Purge Head Pressure & $5.7-\quad \underline{6.0-}$ & 6.3 bar \\
\hline & & Purge Head Flow & 95- $\quad \underline{\mathbf{1 0 0}-} 105 \mathrm{lpm}$ & $95-\underline{\mathbf{1 0 0}}-$ \\
\hline & & Shield Shoe Pressure & $5.7-\quad \underline{6.0}-\quad 6.3$ bar & $5.7-\quad \underline{\mathbf{6 . 0}}-\quad 6.3 \mathrm{bar}$ \\
\hline & & Shield Shoe Flow & 76- $\quad \underline{\mathbf{8 0}-} \quad 84 \mathrm{lpm}$ & $76-\quad \underline{\mathbf{8 0}}-\quad 84 \mathrm{lpm}$ \\
\hline & & Plasma Plume Pressure & 5.7- $\quad \underline{\mathbf{6 . 0}}-6.3$ bar & $5.7-\quad \underline{6.0-}$ \\
\hline & & $\Delta \mathrm{P}$ (cupboard to room) & NA & $<-0.5 " \mathrm{wg}$ \\
\hline & \multirow[t]{7}{*}{ PuPS Outer Can Weld Inspection } & Weld Width & $\geq 0.075$ in. & $\geq 0.075$ in. \\
\hline & & Weld C.L.-to-edge dimension & $0.1575 \pm 0.010$ in. & $0.1575 \pm 0.010$ in. \\
\hline & & Voids & None $>0.030$ & None $>0.030$ \\
\hline & & Weld Undercut & $<0.012$ in & $<0.012$ in \\
\hline & & Leak Rate & $<1 \times 10^{-7} \mathrm{std} \mathrm{cc} / \mathrm{sec} \mathrm{He}$ & $<1 \times 10^{-7}$ std cc/sec He \\
\hline & & Leak Time & NA & $<5$ minutes \\
\hline & & Final Gross Weight & Required Data & Required Data \\
\hline & $\begin{array}{l}\text { Radiographic Inspection } \\
\text { Procedure }\end{array}$ & ASME VIII, UW-51 & ASME VIII, UW-51 & ASME VIII, UW-51 \\
\hline & \multirow{5}{*}{$\begin{array}{l}\text { Weld Metallographic } \\
\text { Examination }\end{array}$} & Weld Penetration & $\geq 0.118$ in. & $\geq 0.130$ in. \\
\hline & & Undercut & $\leq 0.012$ in & $\leq 0.012$ in \\
\hline & & Cracks & None allowed & None allowed \\
\hline & & Maximum void size & $\leq 0.030$ in & $\leq 0.030$ in \\
\hline & & Lack of Fusion & None allowed & None allowed \\
\hline
\end{tabular}




\section{LLNL PUPS WELD QUALIFICATION PLAN}

Appendix 3: LLNL PuPS Data Collected for Laser Weld Process Control (continued)

\begin{tabular}{|c|c|c|c|c|}
\hline Frequency & Process or Procedure & Measured Item & Essential Range & Recommended Range \\
\hline \multirow[t]{6}{*}{$\begin{array}{l}\text { Once every } \\
6 \text { months }\end{array}$} & \multirow[t]{3}{*}{ Laser Power Probe Tests } & $\begin{array}{l}\text { Delivered Inner Can Weld } \\
\text { Laser Power }\end{array}$ & NA & 1378-1450-1522 Watts \\
\hline & & $\begin{array}{l}\text { Delivered Inner Can Cut } \\
\text { Laser Power }\end{array}$ & NA & 1568-1650-1732 Watts \\
\hline & & $\begin{array}{l}\text { Delivered Outer Can Weld } \\
\text { Laser Power }\end{array}$ & 1626-1712-1798 Watts & 1644-1712-1780 Watts \\
\hline & \multirow[t]{3}{*}{ Rotation Speed Test } & Inner Can Weld & NA & $392-\mathbf{4 0 0}-408 \%$ min \\
\hline & & Inner Can Cut & NA & $433-\underline{442}-480 \% / \mathrm{min}$ \\
\hline & & Outer Can & $510-\mathbf{5 2 0}-530 \mathrm{~mm} / \mathrm{min}$ & $510-\mathbf{5 2 0}-530 \mathrm{~mm} / \mathrm{min}$ \\
\hline
\end{tabular}

